\title{
Outcome Uncertainty, the Superstar Effect, Talent and Live Attendance in Professional Boxing
}

\author{
By David Chaplin* \\ Erik Madrigal ${ }^{\dagger}$ \\ Daniel Maguetat
}

\begin{abstract}
The relationship between outcome uncertainty, the superstar effect, talent and live attendance at professional boxing matches is analyzed for forty-three contests. The implied probability the underdog will win (taken from bookmaker odds) is used to model outcome uncertainty, while the time-adjusted average number of Twitter Followers of the combatants in a given boxing match is employed as a proxy for the superstar effect. Utilizing a log-log multivariate regression model (with live attendance as the dependent variable and explanatory variables of outcome uncertainty, the superstar effect, average knockout percentage and a dichotomous variable to capture if one or both combatants is an Olympic Medalist), we find only the superstar effect to have a statistically-significant impact on live attendance for professional boxing matches. These findings support recent evidence from English Premier League Football, the Italian Football League (Serie A and B), U.S. Major League Soccer and the U.S. National Basketball Association that star power is a critical determinant of live attendance and television viewership in professional sports. While owners, managers and marketers go to great lengths to promote competitive balance as a means of generating and maintaining fan interest, the aforementioned findings indicate that greater emphasis should be focused on highlighting the quality of the athletes themselves and, more broadly, their celebrity status.
\end{abstract}

Keywords: competitive balance, star power, boxing

\section{Introduction: Does "Star Power" or Uncertainty of Outcome Drive Live Attendance in Sports?}

It is notable that the seminal article on the economics of sports (Rottenberg, 1956) focused on the importance of competitive balance/outcome uncertainty ${ }^{1}$ (in Major League Baseball). As indicated in later studies by Neale (1964), Baimbridge (1998), Schmidt \& Berri (2001), Fort \& Maxcy (2003) and Chaplin \& Mendoza (2017), among many others, issues of competitive balance are a critical component of analysis for researchers in the field of sports economics. As further evidence of the status afforded competitive balance in the sports economics realm, both Fort (2011) and Leeds and von Allmen (2014), dedicate an entire chapter to the topic in their popular sports economics textbooks. With such a strong emphasis on both measuring the degree of competitive balance existing in sports and praise for the virtues of greater competitive balance that tends to prevail in the literature (that of, ceteris

\footnotetext{
* Professor of Economics, Northwest Nazarene University, USA.

${ }^{\dagger}$ Independent Researcher, Northwest Nazarene University, Nampa, Idaho, USA

* Assistant Professor, University of Aveiro, Agueda School of Technology and Management, Aveiro, Portugal.
} 
paribus, greater outcome uncertainty and thus higher attendance at sporting events), concern over maintaining competitive balance in sports is frequently central to discussions about attendance in sports. Given the evidence provided above, studies of attendance demand (whether live or virtual) in sports need to account for the issue of competitive balance in some fashion.

Complementing studies of outcome uncertainty, an increasing body of literature in the field of sports economics has emerged in recent years, which has placed greater emphasis on "star power" (hereon SP) and talent as more significant drivers of attendance demand than competitive balance, per se (Treme \& Allen, 2011; Franck \& Nuesch, 2012; Hogan, Massey \& Massey, 2013; Sacheti, Gregory-Smith \& Paton, 2014; Ormiston, 2014; Buraimo \& Simmons, 2015; Jewell, 2015; Lewis \& Yoon, 2016; Gooding \& Stephenson, 2016) in National Football League (U.S.), German football, European Rugby Union League, international cricket, Major League Baseball, English Premier League Football, U.S. Major League Soccer, Major League Baseball and the Professional Golfers' Association of America (PGA), respectively.

While all the studies mentioned above downplay the importance of outcome uncertainty as a driver of attendance demand in professional sports, they differ in the emphases they place on SP and talent. Treme \& Allen (2011), Jewell (2015), Lewis \& Yoon (2016) and Gooding \& Stephenson (2016) emphasize the value of SP, per se, as the sine qua non for attendance demand. Hogan, Massey \& Massey (2013), Sacheti, Gregory-Smith \& Paton (2014) and Buraimo \& Simmons (2015) place the greatest emphasis on talent, per se, while Franck \& Nuesch (2012) and Ormiston (2014) find both talent and SP to have statistically-significant impacts on attendance demand.

It is critical for studies of attendance demand in sports to incorporate the factors of outcome uncertainty, SP and talent, as the ultimate generator of demand in sports is the multifaceted element of "fan interest," which includes components of watching or listening to a description of the contest, buying products associated with the contest or "following" the contest (Borland \& Macdonald, 2003) in the broadest sense of the term. In the modern era, one's Twitter Followers provides insights into fan interest regarding individual boxers (or a forthcoming fight they are involved in) and the live or remote attendance demand for a sporting event may also be attributed to the "quality of the contest." This last feature may be subdivided into the components of talent and uncertainty of outcome. Regarding the issue of talent, Rottenberg (2000, p. 11) postulates, "The quality of the game is higher, the more grace and skill which is produced, the larger the number of instances of extraordinary physical achievement that appear in it." The notion that the higher the degree of outcome uncertainty, ceteris paribus, the greater the fan interest (as the result of a heightened sense of drama) is summarized in the following quotations by Madrigal (1995, p. 206): (a sporting contest is)..."a hedonistic experience in which the event itself elicits a sense of drama," Gan, Tuggle, Mitrook, Coussement \& Zillmann (1997, p. 54), "Uncertainty about a game's outcome, then, is seen as an experiential condition that fosters interest and attention in viewers" and Trung, Booth, Brooks, Schnyter "...TV audiences do indeed value 
expected (and actual) close contests, after controlling for other factors" (2015, pp. 533-34).

This paper estimates the impact features of the aforementioned elements of fan interest as follows: uncertainty of outcome (provided by betting odds associated with a given professional boxing contest), SP (given by the timeadjusted average number of Twitter Followers of the combatants in a given contest) and measures of "talent" (provided by a boxer's knockout ratio and if they possess an Olympic medal, bronze silver or gold, in boxing) have on live attendance at professional boxing matches. The OLS regression results indicate only the "superstar effect" (SP) as having a statistically-significant (positive) impact on live attendance.

As one of only three existing studies applying regression analysis to the study of the economics of professional boxing (Balbien, Noll \& Quirk, 1981; Chaplin, 2012a; Chaplin, Brown \& Harris, 2017), this paper contributes to the literature by providing an additional sport-specific (professional boxing) measure of competitive balance and by reinforcing the importance of SP for athletes as a means of increasing live attendance.

\section{Review of the Literature}

Select Background on the Importance of Competitive Balance, SP and Talent on attendance in Team Sports

In a sweeping review of the impact of competitive balance on both live and remote attendance in sports (with their focus entirely on team sports), Borland \& MacDonald (2003, p. 487) conclude that only long-run intra-season and inter-season competitive balance have consistently been found to have a significant positive impact (implying that short-run competitive balance, such as for a particular contest, does not significantly impact attendance). The authors summarize their findings on this matter as follows: "...there is, indeed, reason to question the idea of a relation between match-level competitive balance and attendance...there is little evidence to support the idea that attendance is higher when a 'close' contest is expected." In a similarly broad, ambitious study, O'Reilly, Nadeau, J. \& Kaplan (2011) argue that the competitive balance is the most important cause of a professional sport league's success, indicating that fans are more drawn to a competition if the outcome is uncertain.

As demonstrated in the preceding paragraph and immediately below, there is a lack of general consensus as to the impact competitive balance (whether measured over the short or long run) has on either live or remote attendance in professional sports.

In a study of international cricket, Sacheti, Smith \& Paton (2014) find that both short and long run uncertainty of outcome has a significant impact on attendance demand, but that absolute team strength (which could be categorized as "talent") has better explanatory power for attendance demand than uncertainty of outcome measures. Hogan, Massey \& Massey (2013), in a study of attendance 
demand in European Union Rugby League, come to virtually the same conclusion for rugby as the authors above did for cricket, with absolute team strength demonstrating a much greater impact on attendance demand that either short or medium term uncertainty of outcome. These findings are consistent with the work of Brandes, Franck \& Nuesch (2008), who found that talent (which they categorize as being embodied in "local heroes") have a significant impact of live attendance in German football.

In Major League Baseball, Schmidt \& Berri (2001), find evidence of greater (long-run) uncertainty of outcome increasing live attendance, while Knowles, Sherony \& Haupert (1992) found that greater uncertainty of outcome for individual contests (short-run) had a significant impact on live attendance. Cox (2015) discovers an interesting impact of uncertainty of outcome on live vis-à-vis tv demand for individual matches in English Premier League Football, as those attending the matches live were found to favor more certain outcomes, yet those viewing the matches on tv favored greater uncertainty of outcome. Paul \& Weinbach (2007) similarly found that tv viewers of Monday Night Football (U.S.) favored a high level of uncertainty of outcome (as well as highscoring, quality match-ups between winning teams). In an intriguing study of English football, Alavy, Gaskell, Leach \& Szymanski (2010) analyze minuteto-minute tv viewership and find that uncertainty matters in the sense that viewership decreases as the probability of a given side winning increases. However, viewership was also found to decrease as the probability of a draw in a given match increased (implying that tv viewers of the sport favor clarity in terms of the final outcome of a contest). Schreyer, D. \& Torgler, B (2016) confirm the aforementioned findings of a positive correlation between uncertainty of outcome and tv demand for World Championship Formula I Grands Prix for 400 broadcasts over the period 1993 to 2014.

Dating back to at least the work of Noll (1974) for team sports and Rosen (1981), Adler (1985) and Boorstin (1992) regarding the value of celebrity for its own sake as a means of garnering greater demand (and compensation) for those possessing it, SP has consistently been found to positively influence live and remote attendance, as indicated across a wide array of both team and individual sports in the introduction section of this paper. Ultimately, it appears, one can view uncertainty of outcome (UOO) as a necessary, but not sufficient, condition for driving attendance at sporting events.

Select Background on the Importance of Competitive Balance, SP and Talent on Attendance in Individual Sports

Perhaps the following tweet from ESPN Boxing Analyst and Columnist, Nigel Collins (2016, May 20), most accurately embodies the importance of SP vis-à-vis UOO in professional boxing: "Gotta love the UK fans. David Haye is a 100-to-1 betting favorite over Arnold Gjergjaj, but the O2 Arena is sold out." Given the O2's 20,000 seat capacity, this live attendance figure is quite impressive for a gross mismatch on paper (and, as it turned-out, in the ring as 
well - as Gjergjaj was completely overmatched and knocked out just 35 seconds in to the second round of the contest).

As with team sports, there is evidence supporting the UOO hypothesis, but a great deal of support for SP as a driver of live attendance also exists. In a study of tv demand for PGA Tour events, only one of six measures of competitive balance were found to be statistically-significant, but SP proved to be very significant (Gooding \& Stephenson, 2016). In the Ultimate Fighting Championships (UFC), both UOO and SP were found to positively impact payper-view (PPV) buys. In a study of tv demand for cycling in Spain, UOO was found to have a significant impact, but nationality of the race leader (a measure of SP) was also found to be significant. Focusing on the impact of a poor public image in cycling, Reeth (2013) found that the release of news of doping by competitors had a negative impact on tv demand. In NASCAR, tv viewers were found to favor both short-run and long-run UOO in a study by Berkowitz, Depken II \& Wilson (2011). In a measure designed to estimate the determinants of pay in professional boxing, rather than attendance, Chaplin (2012a) found SP to have a significant impact on the guaranteed purses boxers earn.

As will be explained in more detail in Section IV of this paper, the findings on the relationship between attendance demand and UOO herein are consistent with those of Borland \& MacDonald (2003), in that the short-run UOO that pertains to a particular contest in professional boxing was not found to have a statistically-significant impact on live attendance.

\section{Methodology and the Data Set}

Rationales for the use of Twitter as the Measure of SP and Selection of Choice Variables

While there are a host of social media outlets one can analyze to evaluate athletes' "star power," Twitter was selected for this study for the following reasons: 1). Twitter, according to Sanderson (2013, p. 60), "is viewed as the social media channel 'of choice' for athletes" and 2). The normalization of interest they generate with fans to one number: their Twitter Followers (TF) measure.

In estimating demand for live attendance at professional boxing contests, explanatory variables were selected to represent outcome uncertainty (provided by betting odds converted to their implied probabilities), "talent" (estimated by knockout percentage and possession of an Olympic medal for boxing) and "star power" (estimated by the time-adjusted average Twitter Followers of the combatants in a given contest).

\section{The Data Set}

Data were collected for 43 bouts (86 combatants) which were contested between 2008-2015 and provided complete data on the choice variables indicated above. Betting odds were compiled from reports provided by SB Nation (Bad 
Left Hook), www.badlefthook.com; the given odds were converted to their implied probabilities as reported in "How to convert odds" (2016, May 10). For each contest, the Twitter Followers each boxer had as of March, 2016 were divided by the number of months in which they had an active Twitter account and were added together, providing a time-adjusted average number of Twitter Followers for a given bout. Knockout percentages were provided by BoxRec (www.boxrec.com) and Olympic Boxing results were provided by http://www. databasesports.com/.

\section{The Regression Model}

The regression model utilized is a variation of the examples provided by Berri (2006), Chaplin (2012a) and Chaplin, Brown \& Harris (2017) to estimate wage determination in the National Basketball Association and professional boxing, respectively. The model takes the form:

$$
\ln L A=\alpha+\beta_{0} O U+\beta_{1} \ln T F+\beta_{2} K P+\beta_{3} O M+\beta_{4} C U+\varepsilon
$$

where $\ln L A=$ the natural logarithm of live (paid) attendance ${ }^{2}, \alpha$ is a constant term, OU is a measure of outcome uncertainty provided by the implied probability the betting underdog in a contest will $\operatorname{win}^{3}, \operatorname{Ln} T F=$ the natural logarithm of average time-adjusted Twitter Followers of the combatants in a contest $^{4}, K P$ is career knockout percentage for each boxer, $O M$ is a dichotomous variable where $1=$ Olympic medalist in boxing and $0=$ non-medalist, $C U$ is a dichotomous variable where $1=$ boxing venue at $90 \%$ or greater capacity utilization and $0=$ boxing venue at less than $90 \%$ or greater capacity utilization; $\varepsilon$ is an error term.

\section{Analysis of the Statistical Results}

Descriptive Analysis

For the descriptive analysis, bouts were categorized by the implied probability the underdog would win as follows: $<15 \%=$ low outcome uncertainty; $\geq 15 \%<30 \%=$ moderate outcome uncertainty; $\geq 30 \%<50 \%=$ high outcome uncertainty. The 43 bouts included in the study were quite balanced across these categories, with 13 bouts classified as having low outcome uncertainty, 15 bouts with moderate outcome uncertainty and 15 bouts with high outcome uncertainty. As indicated in Appendix A, both the mean (24.3\%) and median (23.8\%) results for this variable fall within the moderate outcome uncertainty range.

Live attendance averaged 9,453 , with a median value of 8,115 . The Twitter Followers measure employed demonstrated tremendous variation, as the mean value was 17,546 , yet the median was only 1,674 (implying that the existence of a few high-profile bouts with a huge number of Twitter Followers 
for each boxer - e.g., Mayweather v. Pacquaio and Cotto v. Margarito II "pulled-up" the mean up substantially).

Table 1. Descriptive Statistics for Continuous Variables

\begin{tabular}{|c|c|c|c|c|c|}
\hline Variable & Mean & Median & Minimum & Maximum & $\begin{array}{c}\text { Std. } \\
\text { Deviation }\end{array}$ \\
\hline LA & 9,453 & 8,115 & 375 & 21,239 & 5,718 \\
\hline UO & .243 & .238 & .028 & .488 & .120 \\
\hline TF & 17,546 & 1,674 & 126 & 415,635 & 63,463 \\
\hline KP & 58.12 & 60.5 & 35.5 & 87.5 & 9.95 \\
\hline
\end{tabular}

Note: Descriptors as follows: LA = live attendance; UO = implied probability the betting underdog in a contest will win; $\mathrm{TF}=$ average time-adjusted Twitter Followers of the combatants in a contest number of Twitter Followers; $\mathrm{KP}=$ knockout percentage.

\section{Results of the Regression Model}

The model demonstrates quite modest overall goodness-of-fit, with 39\% of the variation in boxers' purses explained by the independent variables. The explanatory variables (each denoted by two-letter abbreviations) fell into three broad categories: 1) Uncertainty of outcome (UO), SP (measured by TF), and "talent" (measured by KP and OM). The model is in log-log form with respect to the relationship between TF and live attendance pay; thus, the coefficient of TF may be viewed as a "Twitter elasticity" measure (a term first coined by Chaplin, Brown \& Harris, 2017, in a paper analyzing the correlation between TF and boxers' pay). That is, the coefficient demonstrates the expected value (in percentage terms) of a one percent change in the number of TF. In this case, the coefficient of 0.26 indicates that, ceteris paribus, a $1 \%$ percent increase in TF corresponds with a 0.21 percent increase in a live attendance. TF was statistically-significant at the $5 \%$ level. The variable for uncertainty of outcome (UO) and measures which could be categorized as "talent" rather than SP, per se, KP and OM, were not found to be statistically significant.

To put these numbers in perspective, consider a hypothetical match drawing 10,000 live fans with the combatants averaging 10,000 (time-adjusted) TF. The addition of $10 \%$ more $T F$ (bringing the total to 11,000 ) would result in a $2.1 \%$ expected increase in attendance, bringing their total to 10,210 , ceteris paribus. Employing data from a study regarding the need for a professional boxers' pension plan implemented at either the federal level or across all state athletic commissions in the U.S (Chaplin, 2012b, p. 451), the average ticket price for a live boxing match in Nevada in 2009 was \$334.15 (\$378.23 in 2017 dollars). Thus, employing the aforementioned average ticket price (in 2017 dollars), an additional 210 live attendees would generate an additional \$93,340 in revenue at the gate. 
Table 2. OLS Regression Results for Live Attendance

\begin{tabular}{|l|l|l|l|l|l|}
\hline Variable & Coefficient & $\begin{array}{c}\text { Heteroskedasticity- } \\
\text { Robust Standard } \\
\text { Error of the } \\
\text { Estimate }\end{array}$ & $\begin{array}{c}\text { T- } \\
\text { Statistic }\end{array}$ & P-Value & $\begin{array}{c}\text { Level of } \\
\text { Statistical } \\
\text { Significance }\end{array}$ \\
\hline Constant & 6.40 & 1.16 & 5.50 & 0.000 & $1 \%$ \\
\hline UO & 1.11 & 0.88 & 1.25 & 0.32 & N/A \\
\hline TF & 0.21 & 0.09 & 2.23 & 0.03 & $5 \%$ \\
\hline KP & 0.01 & 0.02 & 0.37 & 0.72 & N/A \\
\hline OM & -0.12 & 0.38 & -0.28 & 0.78 & N/A \\
\hline CU & 0.65 & 1.16 & 1.71 & 0.096 & $10 \%$ \\
\hline
\end{tabular}

Note: Descriptors as follows: UO $=$ implied probability the betting underdog in a contest will win; $\mathrm{TF}=$ average time-adjusted Twitter Followers of the combatants in a contest number of Twitter Followers; KP $=$ knockout percentage; $\mathrm{OM}$ is a dichotomous variable where $1=$ Olympic medalist in boxing and $0=$ non-medalist; $\mathrm{CU}$ is a dichotomous variable where $1=$ boxing venue at $90 \%$ or greater capacity utilizationand $0=$ boxing venue at less than $90 \%$ or greater capacity utilization. $\mathrm{N}=43 ; \mathrm{DF}=37 ; \mathrm{R}-\mathrm{Squared}=0.18 ; \mathrm{F}$-Statistic $=4.70 ; \mathrm{P}-$ Value $(\mathrm{F})$ $=0.002$. Ramsey RESET test with null hypothesis: $\underline{\mathrm{H}}_{0}$ : model has no omitted variables rendered an F-Statistic of 0.31 and a p-value of 0,82 ; thus we cannot reject the null hypothesis that the model has no omitted variables. The model had a mean VIF of 1.27 , indicating no issues with multicollinearity.

\section{Concluding Remarks and Suggestions for Future Research}

\section{Implications of the Regression Results}

The results found herein are consistent both with the work of Borland \& Macdonald (2003), which demonstrated that short-run UOO (for example, as measured by a single sporting event) does not have a statistically significant impact on attendance and the work on SP in the broad sense (Rosen, 1981; Adler, 1985 and Boorstin, 1992), in team sports (Noll, 1974, Treme \& Allen, 2011; Jewell, 2015 and Lewis \& Yoon, 2016) and individual sports (Tainsky, Salaga \& Santos, 2013; Reeth, 2013 and Gooding \& Stephenson, 2016). However, these findings do not substantiate the uncertainty of outcome hypothesis or the value of talent (as measured by knockout percentage or if the bout featured an Olympic medalist in boxing) as driving attendance demand for live boxing matches.

An implication of these findings is that there is tremendous value in selfpromotion for professional boxers. One can name a litany of boxers with comparable technical styles and records to Floyd Mayweather, Jr. as of this writing (49 wins, 0 losses, 53\% K.O. ratio) - Joe Calzaghe (46 wins, 0 losses, $70 \%$ K.O. ratio), Sven Ottke (34 wins, 0 losses, 18\% K.O. ratio), Ricardo Lopez, Jr., (51 wins, 0 losses, 1 draw, 73\% K.O. ratio) and Roman "Chocolatito" Gonzalez (46 wins, 1 loss, $83 \%$ K.O. ratio) - who earned a tiny fraction of the sums hauled-in by Floyd Mayweather, Jr. over their careers due to their inability to cross-over to a mass audience. As a glaring example of this disparity, ESPN Boxing "Pound-for-Pound King" at the time (September, 2015), Floyd Mayweather, Jr. earned a guaranteed minimum purse of $\$ 32,000,000$ for (what he claimed to be) his final fight against no-hoper, Andre Berto (who had an 
implied probability of winning of only 5.9\% - see Table 3 at the end of this paper). Recent ESPN Boxing reigning "Pound-for-Pound King," Roman "Chocolatito" Gonzalez (espn.com, 2016, April 14) going in to his (world title) bout against huge underdog McWilliams Arroyo - who was listed as $1800+$ in the betting lines, and thus had an implied probability of winning of $5.3 \%$ ("How to convert odds" [2016, May 10]) on April 23, 2016, earned a (careerhigh) guaranteed minimum purse of just $\$ 300,000$ (Rafael, 2016, April 23).

While part of the aforementioned pay differential may be explained by the different weight categories of the boxers (Mayweather boxed in the everpopular and lucrative [The top 10 highest paid...] 147 pound weight class; Gonzalez boxes in the far less popular 112 pound weight class), most of this gap in pay must be explained by the SP phenomenon (as there is little separating the two boxers in terms of talent as measured by their records and designation as "pound-for-pound best" in professional boxing at the time these data were collected). While Floyd Mayweather, Jr. won a bronze medal for the USA in boxing at the 1996 Olympics in Atlanta and had 7.41 million Twitter Followers as of August 24, 2017 Roman "Chocolatito" Gonzalez hails from Nicaragua, speaks no English, had an excellent but very low-key amateur boxing background and had a mere 62.7 thousand Twitter Followers on August 24, 2017.

\section{Implications for Future Research}

The debate about the importance of UOO, SP, and talent as the drivers of live and remote attendance in professional sports has gained even greater momentum in recent years and appears to have no end in sight. Given the popularity (and controversy) surrounding these elements of attendance demand, the three areas presented below appear to be fertile ground for future research.

Additional sport-specific (control) tests of impact of UOO v. SP and talent on live attendance and TV attendance would prove enlightening for academics and practitioners who analyze sports. Within a given sport, it would be attractive to control for the impacts of greater competitive balance v. SP at separate events to compare the impact on attendance. In the world of professional boxing, fight cards with no major stars but competitive "50/50 fights" (known as "trade fights/cards" in the sport) could be compared with cards such as the aforementioned David Haye v. Arnold Gjergjaj match (which appeared to rely entirely on the SP of David Haye to generate live attendance) as one example of such an analysis.

A long-run analysis of UOO in the World Series of Boxing (WSB), begun in 2010 and governed by the International Boxing Association (Lausanne, Switzerland), as it is a boxing competition formed around team competition by city franchise ("About WSB," 2016, June 15), could prove to be a valuable addition to the literature. Such a structure allows for a comparison of the importance of both short-run (specific to a particular inter-franchise match) and long-run (seasonal) UOO. 
As there is on-going debate in the literature on sports regarding fan identification as "casual" vis-à-vis "hardcore," an analysis of the impact of UOO, SP, talent and PPV buys in professional boxing, in keeping with the study of PPV in the Ultimate Fighting Championships by Tainsky, S. Salaga, S. and Santos, C. (2013), would push the analysis provided even further. Samra and Wos (2014, p. 265) provide three characteristics of the hardcore fan - with the word "fan" being used here in its traditional sense, in keeping with its root word: "fanatic" 1). Fans possess a strong and intense emotional attachment with the consumption objects; 2). Fans behave as loyal consumers who exhibit several loyalty behaviors, such as repeating their purchase or patronage, or insisting on staying in the relationship between brands and products. 3). Fans present informal membership behaviors, such as co-production and investment. In contrast to the hardcore fan, the casual fan (which Madrigal, 1995, describes as "theatregoers" or "fair-weather fans") display temporal or situational involvement with their team/sport. Despite their lack of enduring commitment, Quick (2000, p. 150) provides insight into the value of the casual fan regarding demand for sports as follows: "The tribal, hard-core fan is but a minor figure in the professional sportscape. In recent decades a number of other fan segments have been identified, each having a different expectation of the sport experience."

An approach designed to account for the heterogeneity between hardcore and casual fans provides richer insight into the (live or remote) attendance demand behavior of each group. While live attendance at a professional boxing match (in contrast to remote attendance) requires a much greater financial and time commitment (in terms of direct costs of the ticket, auxiliary costs of parking, transport to the venue, et cetera, and the opportunity costs of one's time) and is thus the best measure of demand from the "hardcore" fan, a measure of PPV buys provides more insight into demand from the "casual" audience (as PPV combat sport events draw casual fans who can all go in on a fight for a low price and enjoy an "event" atmosphere akin to the Superbowl in the U.S.). As the "casual" audience often comprises a large share of total demand for a particular sporting event (Quick, 2000), such a bifurcation between categories of sports fans provides an attractive future avenue for analysis. 
Table 3. Complete Data Set

\begin{tabular}{|c|c|c|c|c|c|c|c|c|c|}
\hline Bout & Date & Live Attend & $\begin{array}{l}\text { LN of Live Attend } \\
\text { (Y) }\end{array}$ & UOO & $\begin{array}{l}\text { Avg. Adj. } \\
\text { TF }\end{array}$ & $\begin{array}{l}\text { LN of Adj. Avg. } \\
\text { TF }\end{array}$ & Avg. KOP & OM? & $\begin{array}{l}\text { CU at } 90 \% \\
\text { of above? }\end{array}$ \\
\hline $\begin{array}{l}\text { Mayweather v. } \\
\text { Pacquiao }\end{array}$ & $5 / 2 / 15$ & 16219 & 9.693938673 & 0.385 & 75556 & 11.2326235 & 53.5 & 1 & 1 \\
\hline Broner v. Taylor* & $9 / 6 / 14$ & 8115 & 9.00146948 & 0.114 & 6794 & 8.823743748 & 61.5 & 0 & 0 \\
\hline $\begin{array}{l}\text { Mayweather v. } \\
\text { Guerrero }\end{array}$ & $5 / 4 / 13$ & 14258 & 9.565073432 & 0.174 & 50510 & 10.82993344 & 47.5 & 1 & 0 \\
\hline $\begin{array}{l}\text { Pacquiao v. } \\
\text { Marquez III }\end{array}$ & $11 / 12 / 11$ & 15430 & 9.644068945 & 0.125 & 24470 & 10.10518539 & 61.5 & 0 & 1 \\
\hline $\begin{array}{l}\text { Martinez v. JC } \\
\text { Chavez }\end{array}$ & $9 / 15 / 12$ & 12860 & 9.461876998 & 0.37 & 4578 & 8.429044805 & 62.5 & 0 & 0 \\
\hline Ward v. Dawson & $9 / 8 / 12$ & 7611 & 8.937349848 & 0.182 & 2831 & 7.948457933 & 50.5 & 1 & 0 \\
\hline Khan v. Garcia & $7 / 14 / 12$ & 3417 & 8.136518252 & 0.19 & 9867 & 9.196992009 & 57 & 1 & 0 \\
\hline Chavez v. Rubio & $2 / 4 / 12$ & 15664 & 9.659120365 & 0.25 & 1504 & 7.316065339 & 67.5 & 0 & 0 \\
\hline $\begin{array}{l}\text { Ramos v. } \\
\text { Rigondeaux } \\
\end{array}$ & $1 / 20 / 12$ & 375 & 5.926926026 & 0.247 & 213 & 5.362627759 & 54 & 1 & 0 \\
\hline $\begin{array}{l}\text { Donaire v. } \\
\text { Montiel }\end{array}$ & $2 / 19 / 11$ & 3813 & 8.24617156 & 0.364 & 2965 & 7.994508913 & 62.5 & 0 & 0 \\
\hline Khan v. Judah & $7 / 23 / 11$ & 4554 & 8.423761247 & 0.19 & 9503 & 9.15933464 & 55.5 & 1 & 0 \\
\hline $\begin{array}{l}\text { Bradley v. } \\
\text { Alexander }\end{array}$ & 1/29/11 & 6247 & 8.739856627 & 0.357 & 1074 & 6.978772766 & 40.5 & 0 & 0 \\
\hline Cotto v. Mayorga & $3 / 12 / 11$ & 6486 & 8.777401287 & 0.133 & 3896 & 8.267824122 & 67.5 & 0 & 0 \\
\hline Chavez v. Lee & $6 / 16 / 12$ & 12300 & 2.708050201 & 0.238 & 1935 & 7.568068388 & 62.5 & 0 & 0 \\
\hline $\begin{array}{l}\text { Martinez v. } \\
\text { Cotto* }\end{array}$ & $6 / 7 / 14$ & 21090 & 9.956554273 & 0.364 & 7000 & 8.853665428 & 62.5 & 0 & 1 \\
\hline $\begin{array}{l}\text { DeGale v. } \\
\text { Groves* }\end{array}$ & $5 / 21 / 11$ & 17000 & 9.740968623 & 0.267 & 4905 & 8.498064022 & 65.5 & 1 & 0 \\
\hline Golovkin v. Rubio & $10 / 18 / 14$ & 9323 & 9.140239744 & 0.028 & 1196 & 7.086599723 & 83 & 1 & 1 \\
\hline $\begin{array}{l}\text { Khan v. } \\
\text { Alexander }\end{array}$ & $10 / 20 / 14$ & 7768 & 8.95776801 & 0.313 & 13325 & 9.497412022 & 51.5 & 1 & 0 \\
\hline $\begin{array}{l}\text { DeLaHoya v. } \\
\text { Pacquiao }\end{array}$ & $12 / 6 / 08$ & 14468 & 9.579694593 & 0.385 & 28939 & 10.27295906 & 62.5 & 1 & 0 \\
\hline Rios v. Abril & $4 / 14 / 12$ & 2728 & 7.911324019 & 0.2 & 706 & 3.044522438 & 60 & 0 & 0 \\
\hline
\end{tabular}


Chaplin et al.: Outcome Uncertainty, the Superstar Effect...

\begin{tabular}{|c|c|c|c|c|c|c|c|c|c|}
\hline $\begin{array}{l}\text { Broner v. } \\
\text { Escobedo }\end{array}$ & $7 / 21 / 12$ & 3996 & 8.29304914 & 0.111 & 1674 & 7.423089806 & 57.5 & 0 & 0 \\
\hline Alvarez v. Lopez & $9 / 12 / 12$ & 12860 & 9.461876998 & 0.091 & 7399 & 8.909046261 & 57 & 0 & 0 \\
\hline $\begin{array}{l}\text { Berto v. } \\
\text { Guererro* }\end{array}$ & $11 / 24 / 12$ & 4865 & 8.489821995 & 0.385 & 1233 & 7.117289399 & 57 & 0 & 0 \\
\hline Khan v. Molina & $10 / 15 / 12$ & 2836 & 7.950149888 & 0.105 & 1249 & 7.12975532 & 39.5 & 1 & 0 \\
\hline $\begin{array}{l}\text { Mikey Garcia v. } \\
\text { Salido (co-main)* }\end{array}$ & $6 / 15 / 13$ & 4131 & 8.326274787 & 0.182 & 543 & 6.296846197 & 65.5 & 0 & 1 \\
\hline Khan v. Peterson* & $12 / 10 / 11$ & 8647 & 9.064967719 & 0.133 & 15147 & 9.625561655 & 50.5 & 1 & 1 \\
\hline Porter v. Broner* & $6 / 20 / 15$ & 8138 & 9.004299729 & 0.488 & 2565 & 7.849798507 & 62.5 & 0 & 0 \\
\hline $\begin{array}{l}\text { Donaire v. } \\
\text { Mathebula }\end{array}$ & $7 / 7 / 12$ & 7712 & 8.950532836 & 0.111 & 5949 & 8.691040121 & 51 & 0 & 0 \\
\hline $\begin{array}{l}\text { Trout v. } \\
\text { Rodriguez }\end{array}$ & $6 / 2 / 12$ & 1200 & 7.090076836 & 0.235 & 534 & 6.27971464 & 46.5 & 0 & 0 \\
\hline $\begin{array}{l}\text { Matthysse v. } \\
\text { Olusegun }\end{array}$ & $9 / 8 / 12$ & 377 & 5.932245187 & 0.308 & 169 & 5.132332229 & 61 & 0 & 0 \\
\hline $\begin{array}{l}\text { Golovkin v. } \\
\text { Rosado } \\
\text { (co-main)* }\end{array}$ & $9 / 19 / 15$ & 4131 & 8.326274787 & 0.111 & 1497 & 7.311383839 & 66.5 & 1 & 0 \\
\hline Groves v. Jack* & $9 / 12 / 15$ & 13395 & 9.502636782 & 0.364 & 487 & 6.188174841 & 61 & 0 & 0 \\
\hline $\begin{array}{l}\text { Mayweather v. } \\
\text { Berto* }\end{array}$ & $9 / 12 / 15$ & 13395 & 9.502636782 & 0.059 & 41646 & 10.63695027 & 60.5 & 1 & 0 \\
\hline $\begin{array}{l}\text { Santa Cruz v. } \\
\text { Mares* }\end{array}$ & $8 / 29 / 15$ & 13109 & 9.481054296 & 0.488 & 797 & 6.681033906 & 50 & 0 & 0 \\
\hline $\begin{array}{l}\text { Cunningham v. } \\
\text { Tarver }\end{array}$ & $8 / 14 / 15$ & 5843 & 8.672999643 & 0.385 & 126 & 4.837229101 & 46 & 0 & 0 \\
\hline $\begin{array}{l}\text { Golovkin v. } \\
\text { Lemieux }\end{array}$ & $10 / 17 / 15$ & 20789 & 9.94217928 & 0.125 & 1171 & 7.065301548 & 87.5 & 1 & 1 \\
\hline $\begin{array}{l}\text { Warrington } \mathrm{v} . \\
\text { Brunker* }\end{array}$ & $9 / 5 / 15$ & 10000 & 9.210340372 & 0.267 & 656 & 6.485483053 & 35.5 & 0 & 0 \\
\hline $\begin{array}{l}\text { Matthysse v. } \\
\text { Postol }\end{array}$ & $10 / 3 / 15$ & 7025 & 8.857230494 & 0.348 & 188 & 5.234057414 & 62 & 0 & 0 \\
\hline $\begin{array}{l}\text { Martinez v. } \\
\text { Salido* }\end{array}$ & $9 / 12 / 15$ & 13395 & 9.502636782 & 0.364 & 134 & 4.897993658 & 49.5 & 0 & 0 \\
\hline
\end{tabular}




\begin{tabular}{|l|l|l|l|l|l|l|l|l|}
\hline $\begin{array}{l}\text { Klitschko v. } \\
\text { Jennings* }\end{array}$ & $4 / 25 / 15$ & 17056 & 9.744257327 & 0.118 & 1454 & 7.282065219 & 64.5 \\
\hline $\begin{array}{l}\text { Cotto v Margarito } \\
\text { II* }\end{array}$ & $11 / 3 / 11$ & 21239 & 9.963594393 & 0.357 & 415635 & 12.93756256 & 65 \\
\hline Bradley v. Rios & $11 / 7 / 15$ & 5106 & 8.538171598 & 0.19 & 1434 & 7.26820948 & 50.5 \\
\hline Smith v. Fielding & $11 / 7 / 15$ & 7500 & 8.9226583 & 0.25 & 1025 & 0 & 0 \\
\hline
\end{tabular}

*Live attendance only announced (not specified how many were paid vis-à-vis unpaid)

Notes: ${ }^{1}$ According to Owen and King $(2013$, p. 2) “...competitive balance, how evenly teams are matched... affects the degree of uncertainty over the outcomes of individual matches and overall championships." Thus, the terms "competitive balance" and uncertainty of outcome" are inextricably linked (and therefore used interchangeably throughout this paper), as higher levels of competitive balance are reflected in more uncertain outcomes (Rottenberg, 1956).

${ }^{2}$ Bouts in Appendix $\mathrm{C}$ with an asterisk by the names of the combatants had ive attendance only announced (thus, it was not specified how many were paid vis-à-vis unpaid)

${ }^{3}$ The implied probability the underdog would win in a given contest was calculated from betting odds via "How to convert odds" (2016, May 10).

${ }^{4}$ The total number of TF each boxer had in a given contest was divided by the number of months they have had an active Twitter account and then summed. 


\section{References}

About WSB (2016, June 15). International Boxing Association (WSB). Retrieved from http://www.worldseriesboxing.com/about/

Adler, M. (1985). Stardom and talent. American Economic Review, 75(1), 208-212.

Alavy, K., Gaskell, A., Leach, S. \& Szymanski, S., (2010). On the edge of your seat: Demand for football on television and the uncertainty of outcome hypothesis. International Journal of Sport Finance, 5(2), 75-95.

Baimbridge, M. (1998). Outcome uncertainty in sporting competition: The Olympic Games, 1896-1996. Applied Economics Letters, 5, 161-164.

Balbien, J., Noll, R. \& Quirk, J. (1981). The economics of boxing regulation in California. California Institute of Technology, Social Science Working Paper 366.

Berkowitz, J., Depken II, C. \& Wilson, D. (2011). When going in circles is going backward: Outcome uncertainty in NASCAR. Journal of Sports Economics, 12(3), 253-283.

Berri, D. (2006). Economics and the National Basketball Association: Surveying the literature at the tip-off. In J. Fizel (Editor), Handbook of Sports Economics Research (pp. 21-48). Armonk, NY: M.E. Sharpe, Inc.

Boorstin, D. (1992). The image: A guide to pseudo-events in America. New York, NY: Vintage Books (a division of Random House, Incorporated).

Borland, J. \& MacDonald (R. (2003). Demand for sport. Oxford Review of Economic Policy, 19(14), 478-502.

Brandes, L. Franck, E. \& Nuesch, S. (2008). Local heroes and superstars - An empirical analysis of star attraction in German Soccer. Journal of Sports Economics, 9(3), 266-286.

Buraimo, B. \& Simmons, R. (2015). Uncertainty of outcome or star quality? Television audience demand for English Premier League Football. International Journal of the Economics of Business, first published online 16 March 2015. doi: 10.1080/17430437.2015.1088718.

Chaplin, D. (2012a). Pay and race in world championship boxing. Journal of Economics (MVEA), 38(1), 43-57.

Chaplin, D. (2012b). Blood, sweat and fears: The need for a professional boxers' pension plan. Journal of Sport and Social Issues, 36(4), 442-451.

Chaplin, D., Brown, K. \& Harris, J. (2017). Twitter Followers and guaranteed purses in professional boxing. Working paper, Department of Business and Economics, Northwest Nazarene University, Nampa, ID (USA).

Chaplin, D. \& Mendoza, S. (2017). "The history of competitive balance in Commonwealth Games Boxing." Sport in Society, 20(3), 428-437.

Collins, N. [NigelBoxing]. (2016, May 20). Gotta love the UK fans. David Haye is a 100-to-1 betting favorite over Arnold Gjergjaj, but the O2 Arena is sold out. [Tweet]. Retrieved from https://twitter.com/NigelBoxing/status/733639106534 739968

Cox, A. (2015). Spectator demand, uncertainty of results and public interest: Evidence from the English Premier League. Journal of Sports Economics, first published online December 16, 2015 as doi:10.1177/1527002515619655.

Espn.com. (2016, April 14). Pound-for-pound rankings: With Pacquiao out, Crawford makes a move. Retrieved from http://espn.go.com/boxing/story/_/id/15196829/ terence-crawford-andre-ward-make-jump

Fort, R. (2011). Sports economics, third edition. Boston: Prentice Hall.

Fort, R. \& Maxcy, J. (2003). Competitive balance in sports leagues: An introduction. Comment. Journal of Sports Economics, 4(2), 154-160. 
Franck, E. \& Nuesch, S. (2012). Talent and/or popularity: What does it take to be a superstar? Economic Inquiry, 50(1), 202-216.

Gan, S-L, Tuggle, C., Mitrook, M., Coussement, S. \& Zillman, D. (1997). That thrill of a close game: Who enjoys it and who doesn't? Journal of Sport and Social Issues, 21(1), 53-64.

Gooding, C. \& Stephenson, E.F. (2016). Superstars, uncertainty of outcome, and PGA Tour Television Ratings, Journal of Sports Economics, first published online April 21, 2016 as doi: 10.1177/1527002516637649.

Hogan, V. Massey, P. \& Massey, S. (2013). Competitive balance and match attendance in European Rugby Union Leagues, Economic \& Social Review, 44(4), 425-446.

How to convert odds (2016, May 10). Retrieved from http://www.bettingexpert.com/ how-to/convert-odds

Jewell, R.T. (2015). The effect of marquee players on sports demand. Journal of Sports Economics. Published online before print February 4, 2015, doi: 10.1177/152700 2514567922.

Knowles, G., Sherony, F. \& Haupert, M. (1992). The demand for Major League Baseball: A test of the uncertainty of outcome hypothesis. The American Economist, 36(2), 72-80.

Leeds, M. \& von Allmen, P. (2014). The economics of sports, fifth edition. Boston: Addison-Wesley.

Lewis, M. \& Yoon, Y. (2016). An empirical examination of the development and impact of star power in major league baseball. Journal of Sports Economics, published online March 7, 2016 as doi:10.1177/1527002515626220.

Madrigal, R. (1995). Cognitive and affective determinants of fan satisfaction with sporting event attendance. Journal of Leisure Research, 27(3), 205-27.

Neale, W. (1964). The peculiar economics of professional sports. The Quarterly Journal of Economics, 78(1), 1-14.

Noll, R.G. (Editor). (1974). Government and the sports business. Washington, DC: Brookings Institution.

O'Reilly, N., Nadeau, J. \& Kaplan, A. (2011). Do fans want their team to be competitive in the short-term (the next game) or the long-term (the full season), and does the answer affect management decisions? European Sport Management Quarterly, 11(1), 73-86.

Ormiston, R. (2014). Attendance effects of star pitchers in Major League Baseball. Journal of Sports Economics, 15(4), 338-364.

Owen, P.D. \& King, N. (2013).Competitive balance measures in sports leagues: The effects of variation in season length. NCER Working Paper Series (\#92). Retrieved from http://www.ncer.edu.au/papers/documents/WP92v2.pdf

Paul, R. \& Weinbach, A. (2007). The uncertainty of outcome and scoring effects on Nielsen ratings for Monday Night Football, Journal of Economics and Business 59(3), 199-211.

Quick, S. (2000). Contemporary sport consumers: Some implications of linking fan typology with key spectator variables. Sport Marketing Quarterly, 9(3), 149-156.

Rafael, D. (2016, April 23). Roman "Chocolatito" Gonzalez dominates McWilliams Arroyo to keep flyweight championship. Retrieved from http://espn.go.com/boxi ng/story/_id/15311769/flyweight-world-champion-roman-chocolatito-gonzalez-d ominates-mcwilliams-arroyo-12-rounds

Reeth, D. (2013). TV demand for the Tour de France: The importance of stage characteristics versus outcome uncertainty, patriotism, and doping, International Journal of Sport Finance, 8(1), 39-60. 
Rosen, S. (1981). The economics of superstars. American Economic Review, 71(5), 845-858.

Rottenberg, S. (1956). The baseball players' labor market. Journal of Political Economy, 64(June), 242-258.

Rottenberg, S. (2000). Resource allocation and income distribution in professional team sports. Journal of Sports Economics, 1(1), 11-20.

Sacheti, A. Gregory-Smith, I. \& Paton, D. (2014). Uncertainty of outcome or strength of teams: An economic analysis of attendance demand for international cricket. Applied Economics, 46(17), 2034-2046.

Samra, B. \& Wos, A. (2014). Consumer in sports: Fan typology analysis. Journal of Intercultural Management, 6(4), 263-288.

Sanderson, J., (2013). Social media and sport communication: Abundant theoretical opportunities. In P. Pedersen (Editor), Routledge Handbook of Sport Communication (pp. 56-65).New York, NY: Routledge.

Schmidt, M. \& Berri, D. (2001). Competitive balance and attendance: The case of Major League baseball. Journal of Sports Economics, 2(2), 145-167.

Schreyer, D. \& Torgler, B. (2016). On the role of outcome uncertainty in the tv demand for Formula I Grands Prix. Journal of Sports Economics, first published on January 26, 2016 as doi:10.1177/1527002515626223.

Tainsky, S. Salaga, S. and Santos, C. (2013). Determinants of pay-per-view broadcast viewership in sports: The case of the Ultimate Fighting Championship. Journal of Sport Management, 27(1), 43-58.

The top 10 highest paid boxers of all time. TheRichest. Retrieved from http://www. therichest.com/sports/the-top-10-highest-paid-boxers-of-all-time/

Treme, J. \& Allen, S. (2011). Press pass: Payoffs to media exposure among National Football League (NFL) Wide Receivers. Journal of Sports Economics, 12(3), 370-390.

Trung, M.D., Booth, R., Brooks, R. \& Schnytzer, A. (2015). Do tv viewers value uncertainty of outcome? Evidence from the Australian Football League. Economic Record, 91(295), 523-535. 